\title{
ФОРМУВАННЯ ІНТЕРЕСУ ДО МАТЕМАТИКИ В УЧНІВ У ЗАКЛАДАХПОЗАШКІЛЬНОЇ ОСВІТИ
}

8.Tenishcheva, V. F. (2008). Integrativno-kontekstnaya model formirovaniya professionalnoy kompetentsii [An integrative and contextual model of professional competence formation]. Doctor's thesis. GOU VPO "Moscow State Linguistic University". Moscov. 40 p. [in Russian].

9.Shabes, V. Ya. (1990). Sootnoshenie kognitivnogo kommunikativnogo $\mathrm{v}$ rechemyslitelnoy deyatelnosti (sobytie $i$ tekst) [The ratio of cognitive and communicative items in speech and thinking activity (activity and text)]. Doctor's thesis. "Leningrad State University named after A.S. Pushkin". Leningrad. 500 p. [in Russian].

10.Brown, D. (1994). Principles of Language Learning and Teaching. Englewood Cliffs. San Francisco State University, Prentice Hall Regents, N.J. 311 p. [in English].

11.Clark, H. (1981). Context for Comprehension. in Attention and Performance (Eds.). Hillsdale : Lawrence Erlbaum Ass. pp. 304 - 325. [in English].

Стаття надійшла до редакції 28.08.2020

УДК 372.47

DOI:

Олег Довгий, кандидат фізико-математичних наук, дочент, доиент кафедри педагогіки початкової освіти ДВНЗ “Прикарпатський національний університет імені Василя Стефаника"

\section{ФОРМУВАННЯ ІНТЕРЕСУ ДО МАТЕМАТИКИ В УЧНІВ У ЗАКЛАДАХ ПОЗАШКІЛЬНОЇ ОСВІТИ}

Стаття присвячена проблемі формування інтересу до математики в учнів початкових класів та підлітків. Ця проблема актуалізується сьогодні - у період реформування освіти і входження України у Болонський процес. Розвиток математичної грамотності особистості розглядаємо як одне з актуальних завдань, щзо стоїть сьогодні перед украйнською освітою. Базові навички з математики необхідні випускникам шкіл, оскільки математика розвиває логічне й абстрактне мислення, без яких у сьогоднішньому світі молодій людині не обійтися. Сформувати інтерес до математики - одна з умов формування математичної грамотності особистості школяра. 3-поміж чинників, які позитивно впливають на цей прочес, - позашкільне навчальноосвітнє середовище, яке створює необхідні умови для розвитку в дитини любові та інтересу до математики. Таким середовищем став Університет обдарованої дитини, що діє з 2017 року при Прикарпатському національному університеті імені Василя Стефаника. У Школі иікавої математики за допомогою висококваліфікованих викладачів університету, талановитих студентів створюється сприятлива атмосфера для пізнання математики, розвитку логіки, творчої активності учнів. На заняттях відбувається навчання математики (у поєднанні з логікою, геометрією) у формі гри. Така методика вивчення математики дає відчутні результати: у дітей формується стійкий інтерес до иьього предмета.

Ключові слова: інтерес до математики; иколярі; математика; Університет обдарованої дитини; математичні завдання.

תim. 5.

Oleh Dovhiy, Ph.D.(Physical and Mathematical), Associate Professor of the Primary Education Pedagogy Department, Vasyl Stefanyk Precarpathian National University

\section{FORMATION OF STUDENTS' INTEREST IN MATHEMATICS AT EXTRACURRICULAR EDUCATIONAL INSTITUTIONS}

The article is devoted to the problem of forming interest in mathematics among primary schoolchildren and adolescents. This problem is relevant today - during the reform of education and Ukraine's entry into the Bologna Process. We consider the development of mathematical literacy of the individual as one of the urgent tasks facing Ukrainian education today. Basic skills in mathematics are necessary for school graduates, because mathematics develops logical and abstract thinking, which is essential for a modern young person. One of the conditions for the formation of mathematical literacy of the student's personality is the formation of interest in mathematics. Among the factors that positively influence this process is the extracurricular educational environment, which creates the necessary conditions for the development of a child's love and interest in mathematics. Such an environment has become the University of a Gifted Child, which has been operating since 2017 at Vasyl Stefanyk Precarpathian National University. In the School of Interesting Mathematics with the help of highly qualified university teachers and talented students a favorable atmosphere for learning mathematics, the development of logic and creative activity of students are enabled. Classes at the School of Interesting Mathematics together with the teacher are conducted not only by students of Vasyl Stefanyk Precarpathian National University, but also by students of IvanoFrankivsk Vocational College. This tandem creates a positive emotional and creative atmosphere. The lesson teaches mathematics (in combination with logic, geometry) in the form of a game. The teacher offers younger 
students a thorough comment on the solution of a problem, provides similar tasks, consolidates the material and revises what was learned in the previous lesson. This method of studying mathematics gives tangible results: children develop a lasting interest in this subject.

Keywords: interest in mathematics; schoolchildren; mathematics; the University of a Gifted Child; mathematical tasks.

П остановка проблеми. Розвиток математичної грамотності особистостіодне з актуальних завдань, яке стоїть перед сучасною українською освітою. 32021 p. запроваджується дворівнева (легший і складніший рівень, залежно від потреб вступника) обов'язкова державна підсумкова атестація 3 математики у формі $3 \mathrm{HO}$.

Учневі потрібно дати не лише знання, а й сформувати в нього особистісні якості, компетентності, які допоможуть йому знайти себе в подальшому практичному самостійному житті, реалізувати себе, урешті, стати не тільки активним членом суспільства, а й самодостатньою, успішною, щасливою та впевненою у своїх силах молодою людиною. Базові навички з математики необхідні випускникам шкіл - вона, "цариця наук” - розвиває логічне та абстрактне мислення, без яких у сьогоднішньому світі не обійтися.

Тому важливе місце в цьому процесі вчені відводять проблемам розвитку творчого потенціалу особистості, невід'ємним складником якого є математична грамотність. Ситуація ускладнюється і тим, що, на жаль, інтерес до математики в учнів знижується. Це засвідчують як дані ЗНО з математики, які демонструють випускники українських шкіл, так і показники Міжнародного звіту за результатами міжнародного дослідження якості освіти PISA2018 (PISA - Programme for International Student Assessment), участь у якому Україна взяла вперше. Звіт із результатами презентувала Організація економічного співробітництва i розвитку (ОЕСР) 3 листопада 2019 року в Парижі, він $є$ доступний на їі сайті https:// www.oecd.org/pisa/. Так, показники українських учнів 3 математичної грамотності - у середній частині загального рейтингу країн-учасниць ОЕСР, однак істотно відстають від результатів представників більшості країн ОЕСР. У дослідженні в усіх країнах брали участь переважно підлітки 2002 р. народження, яким на час тестування було від п'ятнадцяти до шістнадцяти 3 половиною років, більшість юнаків та дівчат закінчують здобуття базової середньої освіти [5].

Як відомо, PISA встановлює 6 рівнів математичної грамотності. На найвищому, шостому, школярі здатні узагальнювати інформацію на основі власних досліджень, моделювати складні ситуації, розробляти нові підходи для розв'язування нестандартних задач. Вони можуть точно формулювати свої висновки й аргументи, обгрунтовувати власні дії. На найнижчому, першому рівні учні відповідають на чітко сформульовані завдання, у яких наведено всю необхідну інформацію і які стосуються добре відомих їм контекстів. Вони також можуть виконувати дії, які є очевидними або передбачені чіткими інструкціями [4].

У середньому по країнах ОЕСР такого рівня, за даними Звіту, досягають 2,4 \% учнів. Середні результати учнів чотирьох країн та особливих районів КНР за математичною грамотністю відповідають четвертому рівню. Це Китай (591 бал), Сингапур (569 балів), Макау (558 балів) та Гонконг (551 бал). Результати ще 29-ти країн відповідають третьому рівню (від 482 до 544 балів) - це більшість країн ОЕСР. Для 23-х країн, зокрема й Греції, Ізраїлю, США, Туреччини, Хорватії, середні результати відповідають другому рівню (420-481 бал). Отже, середній рівень математичної грамотності українських учнів відповідає другому рівню (453 бали), який ОЕСР відносить до базових. Такі учні здатні розв'язувати задачі в ситуаціях, що допускають прямі умовиводи, можуть використовувати інформацію з одного джерела, представлену в одній формі. Проте $36 \%$ українських учнів не змогли продемонструвати такий рівень, 3 них 15,6 \% не досягли навіть першого рівня математичної грамотності. За даними Міжнародного звіту, у країнах ОЕСР таких учнів у середньому, відповідно, 24 \% та 9, 1 \%. Водночас близько 38 \% українських учасників показали результати 3-6 рівнів, утім, лише одиниці з них потрапили до шостого рівня. У країнах ОЕСР таких учнів значно більше $-53,8 \%$ [5]. Для українських учнів складними були завдання, що передбачають побудову й аналіз навіть простих моделей і використання певних стратегій розв'язування задач, аргументування своїх дій, оперування відсотками і дробами, символьне подання інформації, використання інформації в нових ситуаціях. Водночас, на відміну від тестів 3НО, де більшість учнів навіть не намагаються шукати відповіді на завдання відкритого типу, учасники PISA-2018 були сміливішими, що привело до кращих результатів [4]. Отже, проблема математичної грамотності учнів $є$ актуальною для української школи. 
Аналіз останніх досліджень і публікацій. Учені досліджують різні аспекти проблеми математичної грамотності школярів. Так, у працях В. Авдєєва, Є. Краснякова, В. Кушнір, І. Осадчого, Р. Романишин, Л. Черкаської, Т. Чернецької, В. Швеця та інших науковців розглядаються особливості теорії та практики навчального процесу в школі, зокрема і сільській, зв'язок ефективності активізації учнів під час навчання із алгоритмізацією навчального процесу, використанням практичних завдань, посиленням прикладної спрямованості шкільного курсу математики тощо. Однак проблема, яку винесли в назву статті, ученими цілісно й грунтовно не вивчалася.

Мета статті - проаналізувати механізми формування інтересу до математики в учнів у закладах позашкільної освіти.

Виклад основного матеріалу. Наукові дослідження з проблеми формування математичних здібностей (інтересу до математики) у закладах позашкільної освіти продиктовані вимогами сьогодення. Аналіз Закону України "Про освіту" дає підстави для твердження: мета освіти - це усебічний розвиток особистості як найвищої цінності суспільства, ії талантів, інтелектуальних, творчих і фізичних здібностей $[1 ; 2]$. Як бачимо, основний освітній документ актуалізує одну із цілей - виховання творчої особистості. Звідси одне 3 ключових завдань освіти на сучасному етапі - формувати покоління, яке спроможне навчатися протягом життя. Математична грамотність особистості може забезпечити ефективність цього процесу. На нашу думку, однією з передумов формування математичної грамотності особистості школяра $є$ формування інтересу до математики, одна 3 функцій якого розвиток математичних здібностей. Під здібностями вчені розуміють властивості душі людини, синтез своєрідних різноманітних психічних процесів і станів людини; які засвідчують високий рівень розвитку загальних спеціальних знань, умінь і навичок особистості, що забезпечують успішне виконання нею тих чи тих видів діяльності $[1,23 ; 2,71]$. Математичні здібності не зводяться винятково до знань, умінь і навичок - вони передбачають ї успішне використання на практиці. Тільки завдяки постійним вправам, а також систематичними заняттями математикою можна підтримати в собі і розвивати далі відповідні здібності $[1,15]$.

Математичні здібності - складне наукове поняття, що має багаторівневу структуру. Його вивчають на міждисциплінарному рівні. Так, у педагогіці та психології це поняття розглядають у вимірі вивчення спеціальних здібностей, які визначають успішність у математичній діяльності. Здібності до математики визначаємо як складну й інтегративну властивість особистості, яка формується на основі природних задатків у процесі взаємодії дитини з навколишнім середовищем і $є$ результатом розвитку психічних процесів (сприйняття, логіки, мислення, уяви, пам'яті) тощо) та умовою успішної життедіяльності особистості. У будь-якій дитині від народження закладене творче начало, яке протягом життя зазнає безліч змін залежно від тієї чи тієї життєвої ситуації, у якій дитина-школяр перебуває: воно або загасає, або навпаки - розвивається.

Тому важливо сформувати інтерес до математики вже на рівні початкової школи, відтак підтримувати та розвивати його. Важливо створити таке середовище, що $є$ благодатним для розвитку математичних здібностей дитини: тут ініціюється інтелектуальна зацікавленість учня, культивується розумова активність, будь-яка інтелектуальна діяльність стимулюється, відтак створюються умови для прояву індивідуальних особливостей тощо.

Таким середовищем, як показав практичний досвід діяльності, є “Університет обдарованої дитини” (УОД) - позашкільний заклад (керівник - доктор педагогічних наук, професор кафедри педагогіки початкової освіти Г. Білавич), який $з$ 2016 року діє при Прикарпатському національному університеті імені Василя Стефаника. Тут створено всі умови для гармонійного розвитку особистості школяра, задоволення й розвитку пізнавальних можливостей дітей, зокрема й формування інтересу до математики. У сучасній школі, на жаль, "губиться" чимало здібних до математики учнів. 3-поміж причин - доволі формалізована і складна, не завжди системна стандартна шкільна математична освіта 3 обовјязковими уніфікованими програмами, дисципліною, змагальністю, тестуванням тощо, що виявляється для особливо творчих учнів неприйнятною, постійно створює стресові ситуації, втрачається бажання займатися математикою. Варто вказати й на недостатній рівень підготовки вчителя до роботи 3 дітьми, які проявляють нестандартність мислення й поведінки [2]. Оцінюючи таких учнів, педагоги відзначають у їхній поведінці демонстративність, упертість, небажання наслідувати позитивні зразки. Такі оцінки, на думку вчених-психологів, є наслідком неадекватного розуміння педагогом особистості й особливостей розвитку обдарованої дитини. Дослідження згадуваного фахівця у галузі психології П. Торренса засвідчують: креативні діти швидко проходять початковий рівень 


\section{ФОРМУВАННЯ ІНТЕРЕСУ ДО МАТЕМАТИКИ В УЧНІВ У ЗАКЛАДАХ ПОЗАШКІЛЬНОЇ ОСВІТИ}

розвитку інтелекту й чинять опір усім видам репродуктивних робіт $[1,27]$. Звідси - і завдання: здійснювати розвиток та навчання обдарованих до математики дітей повинні творчі вчителі, які використовують сучасні досягнення педагогіки, вікової психології, інноваційні методи навчання.

Не випадково сьогодні в педагогічній науці дедалі частіше говорять про додаткове навчання (через систему закладів позашкільної освіти), яке пропонує дітям різноманітні освітні послуги. Ці заклади не такі регламентовані, як скажімо, школа, тому батьки і діти $з$ великим бажанням звертають свої думки до системи позашкільної освіти, саме тут $є$ великі можливості для розвитку творчих здібностей особистості, створення ситуації успіху та свободи щодо зміни видів діяльності тощо. Особливо важливе значення система позашкільної освіти має для розвитку молодшого школяра, коли закладається фундамент для гармонійно розвиненої особистості.

Розглядаючи навчання школярів математики як один із видів пізнавальної діяльності, вважаємо, що ця діяльність належить до пізнання, тобто відображення у свідомості явищ реальної дійсності, а також до розширення і поповнення знань та уявлень про явища і закони природи, суспільства. Створена нами при УОДі Школа цікавої математики, окрім іншого, спрямована на виявлення підвищеного інтересу учнів до математики, розвиток прагнення глибоко зрозуміти зміст навчального матеріалу, розвиток логіки тощо. Завдяки застосуванню цікавих ігор, головоломок, кросвордів, ребусів, різноманітних задач, зокрема й з логіки, тощо в молодших школярів і підлітків насамперед формується інтерес до математики, долається стереотип щодо математики як шкільного предмету (“складна математика”, “нецікава математика”, “нудна математика” і под.). Підкреслимо: заняття у Школі цікавої математики разом з викладачем ведуть студенти не тільки Прикарпатського національного університету імені Василя Стефаника, а й учні Івано-Франківського фахового коледжу. Такий тандем створює позитивну емоційну і творчу атмосферу. На занятті відбувається навчання математики (у поєднанні 3 логікою, геометрією) у формі гри, де поруч 3 інтелектуальним інтенсивом панує творчість, диференційований підхід. Викладач молодшим школярам дає грунтовний коментар щодо розв'язування того чи того завдання, наводить аналогічні завдання, закріплює матеріал, повторює те, що розглядали на попередньому занятті. Така методика вивчення математики дає відчутні результати: у дітей формується стійкий інтерес до цього предмету. Важить і те, що тут створено особливо позитивну емоційну атмосферу [3].

Формуванню інтересу до математики слугує постійне розв'язування 3 дітьми, які відвідують УОД, різноманітних цікавих проблемнопізнавальних завдань, у тому числі й з логічним навантаженням. Унаслідок цього в усіх дітей стимулюються допитливість, пізнавальна активність і розвиваються такі якості, як логічне мислення, кмітливість, винахідливість.

Наведемо окремі приклади завдань, які використовували в УОДі для розвитку математичної грамотності молодших школярів та підлітків. Задача про бетонування приміщень. Власникові крамниці було потрібно терміново винайняти майстрів для бетонування підлоги під плитку у двох великих квадратних приміщеннях. Він запросив дві бригади на один день. Бригаді, що приїхала першою, він запропонував приміщення, сторона якого 12 м, і оплату - 300 грошових одиниць. Майстри цієї бригади, побачивши інше - менше - приміщення, запитали, скільки друний власник може заплатити за бетонування підлоги в ньому. І отримали відповідь: 250 грошових одиниць при тій самій товщині бетону. За яке приміщення вигідніше братися цій бригаді, якщо сторона другого приміщення 10 м?

\section{Розв'язок}

Товщина бетону однакова, отже, співвідношення їх об’ємів буде таким самим, як і площ. Тому слід порівняти їх площі. Застосування знань із категорії "Простір і форма" та "Кількість"

Площа приміщення : $=12 \mathrm{~m} \cdot 12 \mathrm{~m}=144 \mathrm{~m}^{2}$; площа приміщення 2: $=10 \mathrm{M} \cdot 10 \mathrm{M}=100 \mathrm{M}^{2}$.

Ціна за 1 м $^{2}$ бетону приміщення 1: = 300 гр.од. : $144 \mathrm{~m}^{2} \approx 2,08$ гр.од./м²;

Ціна за $1 \mathrm{~m}^{2}$ бетону приміщення 2:= 250 гр.од. : $100 \mathrm{M}^{2} \approx 2,5$ гр.од./ $\mathrm{M}^{2}$.

Інтерпретація математичного результату в термінах реального світу.

Отже, за 1 м² бетону приміщення другий власник готовий платити більше, а тому бригаді вигідніше обрати приміщення 2.

Задачі про числові вирази і дії над ними

Задачі цієї серії розв'язуються методом спроб i помилок. Такий евристичний прийом використовується в тих випадках, коли в того, хто розв'язує, нема конструктивних ідей. Численні спроби приводять до нескінченних помилок i, врешті, зазвичай до випадкового успіху. Це складник будь-яких спроб знаходження шуканого результату методом “сліпого пошуку”. Число спроб залежить від рівня розвитку й інтуїції учня, а також його досвіду в розв'язуванні таких завдань. 


\section{ФОРМУВАННЯ ІНТЕРЕСУ ДО МАТЕМАТИКИ В УЧНІВ У ЗАКЛАДАХПОЗАШКІЛЬНОЇ ОСВІТИ}

До прикладу, поставте в записі 7 • $9+12: 3$ -

2 дужки так, щоб значення одержаного виразу було рівне 23.

Розв'язок. $(7 \cdot 9+12): 3-2=23$.

У записі 88888888 поставте між деякими цифрами знак додавання так, щоб одержався вираз, значення якого рівне $\mathbf{1 0 0 0 .}$

Розв'язок. $888+88+8+8+8=1000$.

Задачі про зважування монет

У найпростіших із таких задач необхідно знайти фальшиву монету (наприклад, найлегшу) за допомогою терезів без важелів.

Загальний спосіб розв'язування цих задач полягає в тому, що ця кількість монет ділиться на три частини (за можливості рівних). При одному зважуванні двох частин з різних частин терезів виділяється частина, що містить фальшиву монету. Далі процес повторюється до тих пір, доки у виділеній частині не залишиться один предмет.

До прикладу, Як за допомогою лише одного зважування виділити із трьох монет одну фальшиву (найлегшу)?

Розв'язок. Кладемо на дві чаші терезів по одній монеті, а третю відкладаємо в сторону. Якщо чаші зрівноважені, то відкладена монета $\epsilon$ фальшивою; якщо ні, то терези відразу покажуть найлегшу фальшиву монету.

Джеррі посперечався 3 Томом, що Том не зможе за три зважування знайти фальшиву монету iз 27 штук. А ви зможете?

Розв'язок. Зможемо. Кладемо на дві чаші терезів по дев'ять монет, а ще дев'ять відкладаємо в сторону. Якщо чаші зрівноважені, то фальшива монета $\epsilon$ серед дев'ятьох відкладених в сторону; якщо ні, то терези покажуть, яка дев'ятка монет легша і серед неї $\epsilon$ фальшива монета. Ще залишилось два зважування і вияснити яка 3 дев'яти монет фальшива. Продовження розв'язку цього завдання точно таке ж як і розв'язок попереднього завдання.

Висновки та перспективи подальших досліджень. Розвиток математичної грамотності особистості розглядаємо як одне 3 актуальних завдань, що стоїть сьогодні перед українською освітою. Базові навички з математики необхідні випускникам шкіл, оскільки математика розвиває логічне й абстрактне мислення, без яких у сьогоднішньому світі молодій людині не обійтися. Сформувати інтерес до математики - одна з умов розвитку математичної грамотності особистості школяра. 3-поміж чинників, які позитивно впливають на цей процес, - позашкільне навчально-освітнє середовище, яке створює необхідні умови для розвитку в дитини любові та інтересу до математики. Таким середовищем став Університет обдарованої дитини, що діє 3 2017 р. при Прикарпатському національному університеті імені Василя Стефаника. У Школі цікавої математики за допомогою висококваліфікованих викладачів університету, талановитих студентів створюється сприятлива атмосфера для пізнання математики, розвитку логіки, творчої активності молодших школярів та підлітків.

\section{ЛІТЕРАТУРА}

1. Богданович М. Математична олімпіада молодших школярів: посібник для вчителя. Київ: Махаон - Україна, 2001. 48 с

2. Довгий О. Самостійна робота з математики для майбутніх учителів початкових класів як умова їхнього професійного зростання. Молодь $i$ ринок. 2019. №12 (179). С. 70-74.

3. Університет обдарованої дитини. URL: https://kidsuniver.blogspot.com/2018/

4. PISA: математична грамотність / уклад. Т. С. Вакуленко, В. П. Горох, С. В. Ломакович, В. М. Терещенко; перекл. К. С. Шумова. Київ: УЦОЯО, 2018. $60 \mathrm{c}$.

5. OECD(2019), PISA2018 Results (Volume I): What Students Know and Can Do, PISA, OECD Publishing, Paris, 352 p. https://doi.org/10.1787/5f07c754-en.

\section{REFERENCES}

1. Bohdanovych, M. (2001). Matematychna olimpiada molodshykh shkoliariv: posibnyk dlia vchytelia [Mathematical Olympiad for junior students: a guide for the teacher]. Kyiv, 48 p. [in Ukrainian].

2. Dovhyi, O. (2019). Samostiina robota $z$ matematyky dlia maibutnikh uchyteliv pochatkovykh klasiv yak umova yikhnoho profesiinoho zrostannia [Independent work on mathematics as a condition of professional growth of future primary school teachers]. Youth \& market. No.12 (179). pp. 7074. [in Ukrainian].

3. University of Gifted Child. Available at: https:/ /kidsuniver.blogspot.com/2018/ (accessed 25 June 2020). [in Ukrainian].

4. PISA: matematychna hramotnist [PISA: mathematical literacy]. (Ed.). T. S. Vakulenko, V. P. Horokh, S. V. Lomakovych, V. M. Tereshchenko. Kyiv, 2018. 60 p. [in Ukrainian].

5. OECD (2019), PISA 2018 Results (Volume I): What Students Know and Can Do, PISA, OECD Publishing, Paris, 352 p. https://doi.org/10.1787/ 5f07c754-en. [in English].

Стаття надійшла до редакції 28.09.2020 